\title{
MODELLING PRICE DYNAMICS IN TURKISH ELECTRICITY MARKET: LESSONS FROM GARCH ESTIMATES
}

\author{
Talat ULUSSEVER ${ }^{*}$ \\ Mehmet Ali SOYTAS ${ }^{* *}$ \\ Hasan Murat ERTUĞRUL ${ }^{* * *}$
}

\begin{abstract}
In this paper, we estimate electricity market volatility in Turkey using various GARCH-class models. Spot price in Turkish electricity market exhibits significant variation and therefore, conditional modelling of the volatility can make us better understand the price dynamics of this important market. We estimate volatilities of weekly prices over the period of January 2010 to April 2017 and compare the performance of various GARCH models that take into account the asymmetric effects, possible mean effects of the volatility, fat-tails of the distribution and persistence of the volatility series. We found time varying volatility is an important feature of the price dynamics in Turkish electricity market and additionally, in modelling volatility, paying attention to the extreme price changes via heavy tailed distributions improves the model fit substantially.
\end{abstract}

Keywords: Electricity Market, Volatility Modelling, GARCH, Nonlinear Modelling, Nonlinear time series.

JEL Classification: C01, C13, C51.

\section{TÜRKIYYE ELEKTRIKK PIYYSASINDA FIYAT HAREKETLERİ: GARCH VOLATILITE TAHMINLERINDEN ELDE EDILLEN ÇIKARIMLAR}

\section{Özet}

Bu makalede Türkiye elektrik piyasası volatilitesi çeşitli GARCH modelleri kullanılarak tahmin edilmiştir. Türkiye elektrik piyasasında spot elektrik fiyatı ciddi dalgalanma göstermektedir. Bu sebeple şartl volatilitenin tahmin edilmesi, ekonomi için ciddi önem arzeden bu piyasada fiyat dinamiklerini daha iyi anlamamıza yardmıcı olacaktır. Ocak 2010-Nisan 2017 dönemi için haftalı fiyat volatilitesi tahmin edilmiş ve çeşitli GARCH modelleri ile elde edilen sonuçların performansları karşılaştırılmıştır. Tahmin edilen GARCH modellerinde asimetrik etkiler, volatilitenin fiyat değişimine olası etkileri, kalın kuyruklu dağılımlar ve volatilitenin kararlılı̆ı dikkate alınmıştır. Bulgular zamana göre değişen

* Asc. Prof. Dr., Ankara Social Sciences University, Capital Markets Board of Turkey, ulussever@gmail.com

** Ass. Prof. Dr., Ozyegin University, Faculty of Business, mehmet.soytas@ozyegin.edu.tr

*** Asc. Prof. Dr., Undersecretariat of Treasury Republic of Turkey, murat.ertugrul@hazine.gov.tr 
volatilitenin Türkiye elektrik piyasasının önemli bir özelliği olduğunu ortaya çıkarmıştır. Buna ek olarak, bu piyasada volatilite modellemesinde kalın kuyruklu dağllimlar kullanılarak ekstrem fiyat değişimlerinin dikkate alınmasının model performansını geliştirdiği bulunmuştur.

Anahtar Kelimeler: Elektrik Piyasası, Volatilite Modellenmesi, GARCH, Doğrusal olmayan Modelleme, Doğrusal olmayan Zaman Serileri.

JEL Sınıflaması: C01, C13, C51.

\section{Introduction}

Last few decades witnessed a major transformation of the electricity markets worldwide. There has been a global trend of liberalization and deregulation in order to provide long run competition and efficiency gains. In terms of industry characteristics electricity trade is no different than most of the other major commodity trades and for this reason it is considered as a technical oriented business ${ }^{1}$. However, there are some specific and unique features that makes electricity trade different from other major commodity markets. Of the most important of these features; storage technology (or lack of it), a requirement for a simultaneous matching mechanism (supply and demand should be met simultaneously at each point in time for a continuous maintenance of the system) and strong seasonality in end user demand can be listed.

The factors that affect the balancing of supply and demand play an important role in price volatility, so they also affect the spot electricity prices and particularly can create problems for price forecasting. Such factors include, power station interruption, imperfect transmission grid reliability, weather conditions changes, related commodity price changes including fuel prices $^{2} 3$. Also with the increasing number of participants in the electricity market as suppliers and distributors with differential roles in the supply-chain, strategic interactions can also be an important factor. This makes spot electricity price volatility and understanding its dynamics critical for all participants of electricity market.

The Autoregressive Conditional Heteroscedasticity $(\mathrm{ARCH})^{4}$ model has been widely applied to commodity markets to capture the volatility dynamics ${ }^{5}$. For instance, Sadorsky ${ }^{6}$ finds that the

$1 \quad$ Murthy et.al., "Forecasting Electricity Prices in Deregulated Wholesale Spot Electricity Market: A Review." International Journal of Energy Economics and Policy, 4(1), 2014, pp. 32-42.

2 G.P. Girish, "Modeling and Forecasting Day-ahead Hourly Electricity Prices: A Review." Proceedings of the International Conference on Business Management \& Information Systems, 2012.

3 R. Weron, "Modeling and Forecasting Electricity Loads and Prices: A Statistical Approach." Wiley, Chichester, 2006.

4 T. Bollerslev, "Generalized Autoregressive Conditional Heteroscedasticity." Journal of Econometrics, 31, 1986, pp. 307-327.

5 R. F. Engle, "Autoregressive Conditional Heteroscedasticity with Estimates of the Variance of United Kingdom Inflation." Econometrica, 50(4), 1982, pp. 987-1008.

6 P. Sadorsky, "Modeling and Forecasting Petroleum Futures Volatility." Energy Economics, 28(4), 2006, pp. 467-488. 
threshold GARCH (or GJR) ${ }^{7}$ fits well for heating oil and natural gas volatilities. He also reports that the standard GARCH $(1,1)$ model fits well for crude oil and unleaded gasoline volatilities. Electricity Energy market is not an exception in terms of applications of GARCH models for volatility modelling. There is huge literature that focuses spot electricity price volatility modeling by employing alternative GARCH (Generalized ARCH model, GARCH) type models in different markets. Thomas and Mitchell ${ }^{8}$, Worthington et. al. ${ }^{9}$ and Higgs ${ }^{10}$ investigate Australian spot electricity market; Knittel and Roberts ${ }^{11}$, Hadsell et. al. ${ }^{12}$, Bowden and Payne ${ }^{13}$, Wang and $\mathrm{Wu}^{14}$ and Hickey et. al. ${ }^{15}$ focused US spot electricity market; Escribano and Villaplana ${ }^{16}$, Lucia and Schwartz ${ }^{17}$, Mugele et al. ${ }^{18}$, Lindstrom and Regland ${ }^{19}$, Gianfreda and Grossi ${ }^{20}$ analyzed European Spot Electricity Market. Also some papers analyzed more than one market such as Escribano and Villaplana ${ }^{21}$ and Chan and Gray ${ }^{22}$.

Thomas and Mitchell ${ }^{23}$ analyzes the volatility properties of Australian electricity market by employing alternative GARCH type models including GARCH, TARCH (Threshold ARCH model, TARCH), EGARCH (Exponential GARCH model, EGARCH) and PARCH (Power

$7 \quad$ Glosten et al., "On the Relation between the Expected Value and the Volatility of the Nominal Excess Return on Stocks." Journal of Finance, 48, 1993, pp. 1779-1801.

8 S. Thomas and H. Mitchell, "GARCH Modeling of High-Frequency Volatilityin Australia's National Electricity Market., Working Paper, RMIT University, Melbourne (Australia), 2007.

9 Worthington et al., "Transmission of Prices and Price Volatility in Australian Electricity Spot Markets: A Multivariate GARCH Analysis.” Energy Economics, 27(2), 2005, pp. 337-350.

10 H. Higgs, "Modelling Price and Volatility Inter-relationships in the Australian Wholesale Spot Electricity Markets." Energy Economics, 31, 2009, pp. 748-756.

11 C.R. Knittel and M.R. Roberts, “An Empirical Examination of Deregulated Electricity Prices." University of California Energy Institute Working Paper PWP-087, 2001

12 Hadsell et al., "Estimating the Volatility of Wholesale Electricity Spot Prices in the US." Energy Journal, 25(4), 2004, pp. 23-40.

13 N. Bowden and J. E. Payne, "Short Term Forecasting of Electricity Prices for MISO Hubs: Evidence from ARIMAEGARCH Models." Energy Economics, 30(6), 2008, pp. 3186-3197.

14 Y. Wang, and C. Wu, "Forecasting Energy Market Volatility Using GARCH Models: Can Multivariate Models Beat Univariate Models?”, Energy Economics, 34(6), 2012, pp. 2167-2181.

15 Hickey et al., "Forecasting Hourly Electricity Prices Using ARMAX-GARCH Models: An Application to MISO Hubs." Energy Economics, 34(1), 2012, pp. 307-315

16 J. Escribano Peaea and P. Villaplana, “Modelling Electricity Prices: International Evidence." Working paper, Universidad Carlos III de Madrid, 2002.

17 J. Lucia and E.S. Schwartz, "Electricity Prices and Power Derivatives: Evidence from the Nordic Power Exchange." Review of Derivatives Research, 5(1), 2002, pp. 5-50.

18 Mugele et.al., "Stable Modeling of Different European Power Markets." Investment Management and Financial Innovations, 2 (3), 2005, pp. 65-85.

19 E. Lindstrom and F. Regland, "Modeling Extreme Dependence between European Electricity Markets." Energy Economics, 34(4), 2012, pp. 899-904.

20 A. Gianfreda and L. Grossi, "Forecasting Italian Electricity Zonal Prices with Exogenous Variables." Energy Economics, 34(6), 2012, pp. 2228-2239.

21 Escribano Peaea and Villaplana (2002), Ibid.

22 K.F. Chan, and P. Gray, "Using Extreme Value Theory to Measure Value at Risk for Daily Electricity Spot Prices." International Journal of Forecasting, 22(2), 2006, pp. 283-300.

23 S. Thomas and H. Mitchell (2007), Ibid. 
ARCH model, PARCH) specifications. They found that PARCH model superior in the NSW, QLD and SNOWY regions; however; for in QLD and SA regions EGARCH model is preferred. Worthington et al. ${ }^{24}$ investigate the spillover of the spot electricity prices and spot electricity price volatility by focusing five regional electricity market in Australia by employing Multivariate GARCH model. They found significant volatility spillovers in all investigated markets which indicates strong ARCH and GARCH effects and a shock in one market has direct effect on the other markets price volatility. Higgs ${ }^{25}$ examines the inter-relationship of the spot electricity prices for four regional market in Australia by employing alternative GARCH type models and correlation models. She found that univariate GARCH $(1,1)$ model shows the presence of positive mean spillover between all four market. Knittel and Roberts ${ }^{26}$ analyzes California Spot market by comparing forecast performance of EGARCH based models. They found high degree of persistence in the price level and some specific characteristics unique to electricity prices. Also they found inverse leverage effects.

Hadsell et. al ${ }^{27}$ investigate volatility of wholesale electricity market for five US market over time and across markets employing TARCH model. They found negative trend in the ARCH term and significant negative asymmetry for all markets. Also they found regional properties for each markets according to persistence of volatility, seasonality and asymmetry. Bowden and Payne ${ }^{28}$ analyzes the spot electricity prices for five MISO (Midwest Independent Transmission System Operator) pricing hub by employing ARIMA, ARIMA-EGARCH and ARIMA-EGARCH-M models. They compare the alternative models according to in sample and out-sample forecasting performance. They found that no model dominates the others in in sample forecasting. However, ARIMA-EGARCH-M model found superior for out-sample forecasting performance.

Hickey et. al. ${ }^{29}$ analyze forecast performance of five MISO pricing hub by employing four ARMAX-GARCH volatility models using hourly data. They found that spot electricity price volatility has regional properties and APARCH (Asymmetric Power ARCH model, APARCH) model performs well in deregulated markets; however, in regulated markets simple GARCH model captures volatility dynamics well. Wang and $\mathrm{Wu}^{30}$ investigates spot oil and energy market volatility forecast by employing both univariate and multivariate GARCH type models for US market and they found that univariate models have superior for analyzing asymmetric effects and univariate GARCH models has superior performance from multivariate models according to crack spread volatility forecasting. Lucia and Schwartz ${ }^{31}$ investigates the behavior of the Nord Pool Spot electricity prices and their implications on derivation pricing by employing alternative

24 Worthington et al. (2005), Ibid.

25 Higgs (2009), Ibid.

26 Knittel and Roberts (2001), Ibid.

27 Hadsell et al. (2004), Ibid.

28 Bowden and Payne (2008), Ibid.

29 Hickey et al. (2012), Ibid.

30 Wang and $\mathrm{Wu}$ (2012), Ibid.

31 Lucia and Schwartz (2002), Ibid. 
factor models. They found that the systemic seasonal patterns have a critical role in explaining the shape of the futures/forward curve. Mugele et al. ${ }^{32}$ analyzes the volatility properties of the different European power markets by employing alternative ARCH/GARCH models and found different specific properties for each markets. Lindstrom and Regland ${ }^{33}$ analyze the Six European Spot Electricity market by employing Markov Regime Switching models. They found positive relationship between extreme event frequency and the amount of renewable sources in the power system. Gianfreda and Grossi ${ }^{34}$ investigate the effects of intra-daily information on explaining and forecasting the conditional volatility of daily electricity returns for Italy by employing ARCH (1) and GARCH $(1,1)$ models. They found that the volatility persistence decreased when taking into consideration the inclusion of the intraday information. Chan and Gray ${ }^{35}$ investigates conditional mean and conditional volatility of spot electricity price returns by employing EGARCH model for Australia, Canada, Europe and US spot markets in order to take into consideration leverage effect. Moreover, they used extreme value theory (EVT) in order to model the tails of the return distribution. They found that their EVT based EGARCH model superior according to their out sample VaR forecasting. Escribano and Villaplana ${ }^{36}$ investigates volatility properties of spot electricity prices for eight electricity markets by employing eight different nested model and they found that electricity spot prices are mean reverting with volatility clustering properties.

This paper investigates the volatility dynamics of electricity energy spot prices in Energy Exchange Istanbul (EXIST). Up to our knowledge there is no previous study that focus on the persistence of volatility and its characteristics in EXIST. In doing so, we contribute to the literature, by finding time varying volatility is an important feature of the price dynamics in Turkey. Additionally, we acknowledge that in modelling volatility in EXIST, paying attention to the extreme price changes via heavy tailed distributions is a major way to improve model fit. These findings are important since electricity price volatility can greatly influence other product price volatilities. For this reason, forecast of electricity price volatility using well-known volatility models which take possible asymmetric effects, possible mean effects of the volatility, fat-tails of the distribution and persistence of the volatility series into account, can improve market participants' strategies; for instance, in terms of hedging strategies, volatility spillover or correlations among energy markets. Also modeling and forecasting of volatility are important for the financial markets by two reasons in general; riskiness of an asset is important determinant of price and volatility is used proxy for risk and, conditional variance should be defined correctly in order to make efficient econometric forecasts based on conditional average ${ }^{37}$. For instance, Ertuğrul et al. ${ }^{38}$ develop a nonlinear forecasting model for

32 Mugele et al. (2005), Ibid.

33 Lindstrom and Regland (2012), Ibid.

34 Gianfreda and Grossi (2012), Ibid.

35 Chan and Gray (2006), Ibid.

36 Escribano and Villaplana (2002), Ibid.

37 H.M. Ertuğrul, “Türkiye’de Döviz Kuru Volatilitesi ve Enflasyon İlişkisi.” PhD. Dissertation, Hacettepe University, Ankara, 2012.

38 Ertuğrul et.al., "Short-term Price Prediction in Electricity Market Using Nonlinear Excess Demand Specification.", 
Turkish electricity prices where the conditional variance is also time varying. As a basic rule of finance theory, the increase in volatility leads to an increase in risks, i.e. volatility is accepted as a risk indicator. Risks of different assets in the markets are compared by looking at their volatilities ${ }^{39}$.

In this paper, we present volatility models for weekly price of electricity in Turkey. The electricity market transformed in Turkey to adapt a competitive market from an oligopolistic state operated structure, therefore pricing is based on demand only recently. The recent change in the market structure brings modern statistical techniques to bear on analysis in a forecasting environment long dominated by predictions based on the immediate experience of industry practitioners, or prediction tools only concerned about the supply side of the market. Our approach in this paper is to estimate deterministic GARCH type volatility processes for the spot electricity price. For this reason, we tried to investigate the volatility properties of the spot electricity prices of Turkey covering 10.01.2010-21.04.2017 periods by employing weekly data including 381 observations. We employed the logarithmic difference of the electricity prices and used return rates as usual. ${ }^{40}$

The remainder of this paper is organized as follows. Section 2 gives general information about the Turkish Electricity Market. In Section 3, a description of GARCH models employed in this paper are explained. Section 4 describes the data and general descriptive statistics. Section 5 represents the empirical results from the GARCH estimations. Section 5 concludes and discusses future research.

\section{Turkish Electricity Market}

In Turkey, electricity prices are formed at Energy Exchange Istanbul (EXIST). There exists a DayAhead Market at EXIST where the main price for the next day is determined by a matching mechanism. Actually there are two price series in a particular day. One is the spot price determined in the aforementioned Day-Ahead Market which is the series used in this paper. This price is determined via a mechanism that matches electricity demand/supply from the previous day. The other is the spot price during the day. Unlike the predetermined price from the Day-Ahead Market, this can show variability in response to unforeseen hourly mismatches during the day.

Market participants quote their bid and ask prices to the market maker (EXIST) and, a price for each hour for the following day is determined. The EXIST handle the data reporting and maintenance of the system and report hour, day, month, and year information of the transaction volume and the unique hourly prices for research purposes. There is a price for each hour of the day and therefore, 24 prices from 12:00 A.M. to 11:00 P.M. in 24 hourly increments are available. Table 1 summarizes the information available from the market in a particular day.

Working Paper, Ozyegin University, 2017.

39 H.M. Ertuğrul, “Türkiye'de Döviz Kuru Volatilitesi Modellemesi.” Unpublished Manuscript, Undersecretariat of Treasury, Republic of Turkey, Ankara, 2010.

40 We first checked the stationarity properties of the logarithmic electricity price variable by employing Ng-Perron test and we found the electricity price variable is I(1). So we take first difference of the variable in order to work with the stationary variable. 
Figure 1 shows the daily prices formed from this market structure during the day. A main characteristics of the daily electricity prices can be seen immediately from Figure 1 that the prices for different hours can show substantial variation during the day. This property is not specific to EXIST but is a general characteristics of a market such as electricity since production at different periods of the day can be affected by many natural factors. The lack of an efficient storage technology also is a major characteristic of this market. This prevents the market from smoothing the prices during the day. Each day until 11:30 A.M., market participants notify the Market Operator about their dayahead market offers via a system called MMS system. The details of the market making process can be found at the Energy Exchange İstanbul (EXIST) website ${ }^{41}$.

Table I: Variables

\begin{tabular}{|l|l|l|}
\hline & Variable & Explanation \\
\hline 1 & weekday & day of the week \\
\hline 2 & hour & hour of the day \\
\hline 3 & day & day information \\
\hline 4 & month & month information \\
\hline 5 & year & year information \\
\hline 6 & price & price level \\
\hline 7 & volume & volume level \\
\hline
\end{tabular}

The accurate prediction of volatility can be vital for market participants in electricity exchange. We propose a weekly volatility estimation framework and sort out the best performing model(s) and their characteristics in this paper, so this is actually very in line with the missions of EXIST in informing market participants about the price dynamics. This will help all of the stakeholders in better forming their expectations and also will benefit Turkish commodity markets in general. Therefore, we hope that the results of the study can be benefited at large.

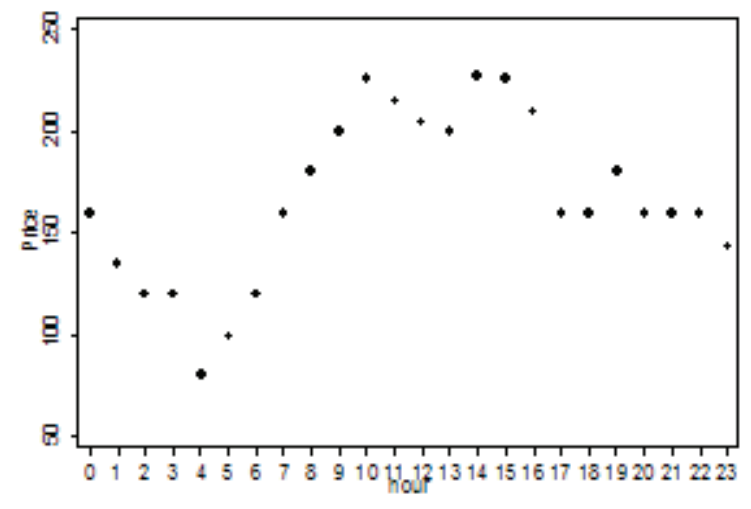

Figure I: Hourly Prices

41 Energy Exchange Istanbul, Intra-day Market, https://www.epias.com.tr/en/intra-day-market/introduction, , Access Date (20.09.2017) 


\section{GARCH Models}

We employ GARCH model, GARCH in Mean model, TGARCH or GJR-GARCH model as alternative models;

GARCH (p, q) process can be represented as in equation 1;

$\varepsilon_{t} / \psi_{t-1} \sim N\left(0, h_{t}\right)$

$\varepsilon_{\mathrm{t}}=y_{\mathrm{t}}-x_{\mathrm{t}} \beta$

$\varepsilon_{\mathrm{t}}=v_{\mathrm{t}} \sqrt{h_{\mathrm{t}}} \quad$ and $\quad \sigma_{v}{ }^{2}=1$

$h_{\mathrm{t}}=\alpha_{0}+\sum_{i=1}^{q} \alpha_{i} \varepsilon_{\mathrm{t}-i^{2}}+\sum_{j=1}^{p} \beta_{j} h_{\mathrm{t}-j}$

where; $\varepsilon_{t}$ is the stochastic process with real value and discrete time, $\psi_{t}$ represents the information set with all relevant information at time $t, y_{t}$ is the series for which the volatility is going to be modelled, $x_{t}$ represents the vector of independent variables that possibly can include lag values of $y_{t}$, and finally $\beta$ is the vectors of unknown parameters ${ }^{42}$.

We can rearrange equation (1) with lag polynomials. If, $L \varepsilon_{t}=\varepsilon_{t-1}$;

$A(L)=\sum_{i=1}^{q} a_{i} L^{i}=a_{1} L+a_{2} L^{2}+\cdots+a_{q} L^{q}$

$B(L)=\sum_{i=1}^{p} b_{i} L^{i}=b_{1} L+b_{2} L^{2}+\cdots+b_{p} L^{p}$

Equation (1) can be rearranged by employing the lag polynomial form in equation (2), then we obtain equation (3) as follows ${ }^{43}$ :

$\operatorname{Var}\left(\varepsilon_{t} / \psi_{t-1}\right)=h_{t}=a_{0}+A(L) \varepsilon_{t}^{2}+B(L) h_{t}$

Engle et. all. ${ }^{44}$ Modified the classical ARCH model by modeling the average of a series as a function of its own conditional variance. So, they added the average of the series to conditional variance equation. Such a model has found widespread application in the stock market literature where the variance of the returns is considered as a risk measure. Excess return model of Engle et. all ${ }^{45}$ is presented in equation (4)

$y_{t}=\mu_{t}+\varepsilon_{t}$

In equation (4), the expected excess return risk resulting from holding long-term assets is equal to the premium.

42 Bollerslev (1986), Ibid.

43 Bollerslev (1986), Ibid.

44 Engle et.al., "Estimating Time Varying Risk Premia in the Term Structure: The ARCH-M Model." Econometrica, 55, 1987, pp. 391-407.

45 Engle et al. (1987), Ibid. 
$E_{t-1} y_{t}=\mu_{t}$

The risk premium is an increasing function of the conditional variance of the return. That is, higher conditional variance leads to higher risk premiums for long-term asset holdings of individuals. Mathematically, if; $\boldsymbol{h}_{\boldsymbol{t}}$ is conditional variance of $\boldsymbol{\varepsilon}_{t}$, the risk premium can be expressed as

$\mu_{t}=\beta+\delta h_{t}$

In equation (7), $\boldsymbol{h}_{\boldsymbol{t}}$ is an $\mathrm{ARCH}(\mathrm{q})$ process.

$h_{t}=\alpha_{0}+\sum_{i=1}^{q} \alpha_{i} \varepsilon_{t-i}^{2}$

We obtain ARCH in Mean model by combining equation (4), (6) and (7). If all three equations are merged, the ARCH-M model can be written as:

$y_{t}=\beta+\delta h_{t}+\varepsilon_{t}$

As can be seen from equation (8), conditional average of $y_{t}$ depends its own conditional variance.

Difference between ARCH in mean model and ARCH model is the fact that conditional variance or conditional standard deviation is included in the set of explanatory variables in the conditional mean function in the former ${ }^{46}$. GARCH in mean model is the generalized version of this representation where the conditional variance follows a GARCH $(\mathrm{p}, \mathrm{q})$ process instead of an $\operatorname{ARCH}(q)$.

Glosten et.al. ${ }^{47}$ developed a GARCH model which takes the different effects of good and bad news on volatility into account. Therefore, the threshold GARCH model is also called GJRGARCH.

$h_{t}=\alpha_{0}+\sum_{i=1}^{q} \alpha_{i} \varepsilon_{t-i}{ }^{2}+\gamma \varepsilon_{t-1}{ }^{2} I_{t-1} \sum_{j=1}^{p} \beta_{j} h_{t-j}$ presented below;

$I_{t-1}=\left(\begin{array}{c}1, \varepsilon_{t-1}<0 \\ 0, \varepsilon_{t-1} \geq 0\end{array}\right)$

The only difference between TGARCH and GARCH model is the $\gamma \varepsilon_{t-1}{ }^{2} I_{t-1}$ term in equation (9). $I($.$) function in equation (9) is stated as dummy variable or indicator function { }^{49}$.

If the asymmetry parameter is greater than zero, this indicates a leverage effect. If the asymmetry parameter is positive and statistically significant, this indicates that positive shocks cause less

46 C. Brooks, "Introductory Econometrics for Finance.", Cambridge University Press, 2002.

47 Glosten et al. "On the Relation Between the Expected Value and the Volatility of the Nominal Excess Return on Stocks." Journal of Finance, 48, 1993, pp. 1779-1801.

48 Glosten et al. (1993), Ibid.

49 Brooks (2002), Ibid. 
volatility than negative shocks or in terms of market information flow, negative news leads to more volatility than positive news.

TGARCH $(1,1)$ model is represented in equation (10).

$$
h_{t}=\alpha_{0}+\alpha_{1} \varepsilon_{t-1}{ }^{2}+\beta_{1} h_{t-1}+\gamma \varepsilon_{t-1}{ }^{2} I_{t-1}
$$

In equation (10), the effect of good news on conditional variance is equal to $\alpha_{1}$ and the effect of bad news on conditional variance is equal to $\alpha_{1}+\gamma$.

The financial time series does not usually exhibit normal distribution characteristics and usually exhibits some features such as thick tail, volatility cluster, asymmetric response and leverage effect ${ }^{50}$. Table 2 indicates that spot electricity price changes are not normally distributed. For this reason, in the empirical part as a common practice in the literature, we estimated alternative distributions in the specifications beside normal distribution. We estimated alternative GARCH type deterministic models and compared them according to log likelihood values. The model which maximizes log likelihood function is selected as the best fit model. The conditional heteroscedasticity of the best fit model used as proxy of volatility of Turkish electricity prices.

\section{Data}

We estimated alternative GARCH type volatility models for Turkish spot electricity prices using weekly data from EXIST covering the period from January 2010 to April 2017. The data includes 381 weekly observations. The descriptive statistics of our data used in the estimation is given in Table 2. Average weekly change of spot electricity prices in our sample is $\% 0.02$ and median value is $\%-0.27$. Maximum and minimum values are $\% 50.63$ and - \%57.15 respectively and standard deviation is 13.79 . This imply that there is high variation on spot electricity price changes. Moreover, normal distribution assumption is not valid for spot electricity price change according to Jarque-Bera test. For this reason, we consider alternative distributions such as t-distribution and GED in the empirical applications. Skewness value of - 0.157 indicates that asymmetricity of the distribution might not be a concern, whereas the kurtosis value of 5.486 suggests the existence of fat tail characteristics of the distribution of the spot price changes.

50 Wang et.al., “A Flexible Parametric GARCH Model with an Application to Exchange Rates." Journal of Applied Econometrics, 16(4), 2001, pp. 521-536. 
Table 2: Descriptive Statistics

Weekly Data (381 observations - January 2010-April 2017)

$\begin{array}{ll}\text { Average } & 0.0190 \\ \text { Median } & -0.2650 \\ \text { Maximum } & 50.627 \\ \text { Minimum } & -57.152 \\ \text { Standard Deviation } & 13.789 \\ \text { Skewness } & -0.157 \\ \text { Kurtosis } & 5.486 \\ \text { Jarque-Bera Test } & 99.364 \\ \text { Prob Value - JB } & 0.0000\end{array}$

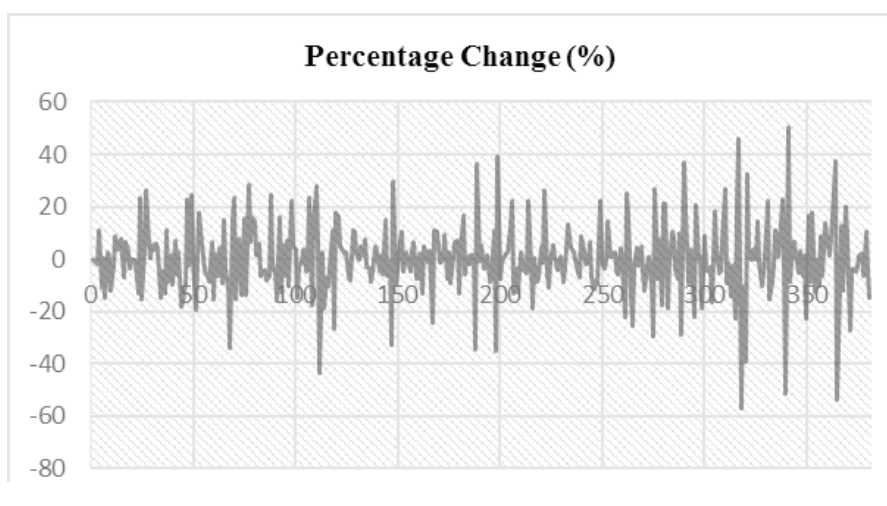

Price (Turkish Lira)

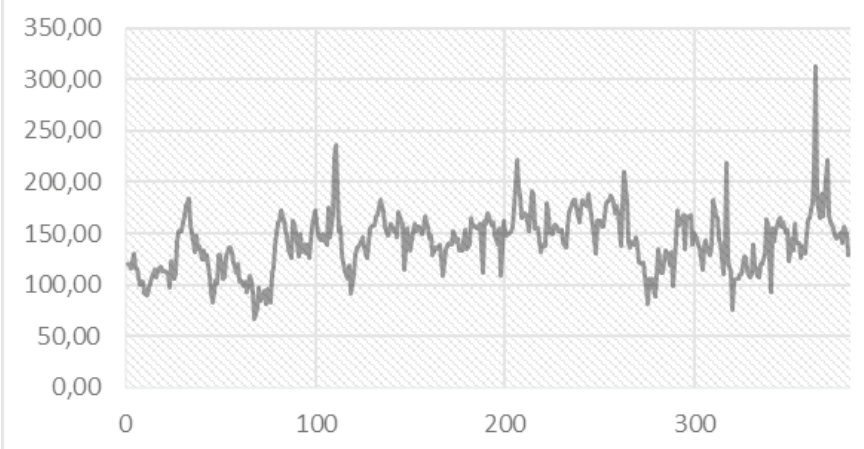

Figure 2: Weekly Spot Prices for the Period: 2010-2017

First graph in Figure 2 also confirms the high variation of the spot electricity price. The spot price shows peaks and downs with significant persistence during the period of January 2010 to April 
2017 as can be seen from the figure. In the bottom graph of Figure 2 we show the time series behavior of the spot price changes.

\section{Empirical Results}

The estimation of the model parameters is conducted using maximum likelihood. The comparisons therefore are based on the model likelihoods. Models with different specifications take into account the asymmetric effects, possible mean effects of the volatility and persistence of the volatility series. All of the estimated models are of the ARCH/GARCH form, meaning the conditional variance is a deterministic function. In Turkish electricity market, after the establishment of the EXIST, the volatility is aimed to be reduced. Since one of the main goals of the exchange markets in general is to decrease price uncertainty, with no exception the price variations (without foreseeable reasons) in Turkish electricity market are aimed to be minimized. In a market like electricity exchange, sudden price changes due to supply side shocks are common. The production and distribution channels are spread across different geographical locations, and also they use different technologies; some prone to system failures more than others. However, using back-up systems and secondary markets are widely used tools to regulate the price in the case of those type of supply shocks. Also less often, sometimes demand cannot be fulfilled at the sustained level of production, possibly due to weather conditions, and other irregularities. All of these factors can lead to an extreme change in price.

In the empirical application, volatility for the weekly price changes in EXIST are estimated via various GARCH models. The total number weeks under consideration in the application is 381, covering the dates from January 2010 to April 2017. As demonstrated in Table 3, the price changes exhibit significant variation over years.

Table 3: Yearly Distribution of Weekly Price Changes

\begin{tabular}{|c|c|c|c|c|c|c|c|}
\hline \multicolumn{8}{|c|}{ Absolute Price Change (\%) } \\
\hline Year & Mean & $\begin{array}{l}\text { Standard } \\
\text { Deviation }\end{array}$ & $>10$ & $>17$ & $>22$ & $>27$ & $>35$ \\
\hline 2010 & -0.25 & 10.8 & 16 & 6 & 4 & 0 & 0 \\
\hline 2011 & 0.58 & 12.5 & 21 & 6 & 5 & 2 & 0 \\
\hline 2012 & 0.08 & 13.2 & 18 & 9 & 6 & 4 & 1 \\
\hline 2013 & 0.43 & 13.0 & 14 & 6 & 6 & 4 & 3 \\
\hline 2014 & -0.16 & 8.7 & 9 & 4 & 3 & 0 & 0 \\
\hline 2015 & -0.08 & 15.2 & 23 & 17 & 7 & 3 & 1 \\
\hline 2016 & 1.23 & 19.9 & 24 & 14 & 11 & 7 & 6 \\
\hline $2017^{\star}$ & -5.20 & 16.8 & 7 & 3 & 2 & 2 & 1 \\
\hline 2010-2017 & 0.02 & 13.8 & 132 & 65 & 44 & 22 & 12 \\
\hline \multicolumn{3}{|c|}{ Theoretical Probability } & $47 \%$ & $22 \%$ & $10.0 \%$ & $5.0 \%$ & $1.0 \%$ \\
\hline \multicolumn{3}{|c|}{ Empirical Probability } & $35 \%$ & $17 \%$ & $11.6 \%$ & $5.8 \%$ & $3.2 \%$ \\
\hline
\end{tabular}

${ }^{\star}$ first 4 months data 
For instance, 2014 is a year with extremely low volatility where almost no sudden extreme change in weekly prices is observed. On the other hand, 2015 and 2016, and to a lesser degree 2013 demonstrate some large weekly price variations. For this reason, before estimating the GARCH models for the full sample period using all available data, we first studied the underlying distributions of price series in each year. This informed us about the clustering of extreme price changes over years and therefore, we can better understand in which particular years the prices contribute more to the overall volatility. The fat tail characteristics of the distribution can be seen from the histogram of the spot price changes in Figure 3. Both large decreases and increases in price have relatively significant share in the overall frequency. When we examine Table 3 in detail, extreme changes that are only \%1 likely in a normal distribution happens $3.2 \%$ of the time in the real data. Of those changes 6 out of 12 have happened in year 2016. We can also see this from the unconditional standard deviation estimation of year 2016 as 19.9 which is more than the double the unconditional volatility of year 2014. 2015 is also a year with high volatility with an unconditional standard deviation of 15.2. Seven price changes more than $22 \%$ and 3 price changes more than $27 \%$ in absolute value happened in this year. There is also one price change over 35\% in this particular year. Taking the trend over years in Table 3, we can see a first increasing, then decreasing pattern of the weekly price series' volatility. The other characteristics we can observe from the results is the relatively higher percentage of extreme changes compared to the ones that had been realized if the price changes would follow a conditional Normal distribution. The bottom two rows of Table 3 present a comparison of the theoretical probabilities from a Normal distribution if the series would follow a conditional Normal distribution and the empirical probabilities derived from the data. The respective $10 \%, 5 \%$ and $1 \%$ probabilities from the Normal distribution corresponds to $11.6 \%, 5.2 \%$ and $3.2 \%$ in the empirical distribution. This confirms the possibility of fat tails of the distribution of spot price changes which might be overlooked by normality assumption.

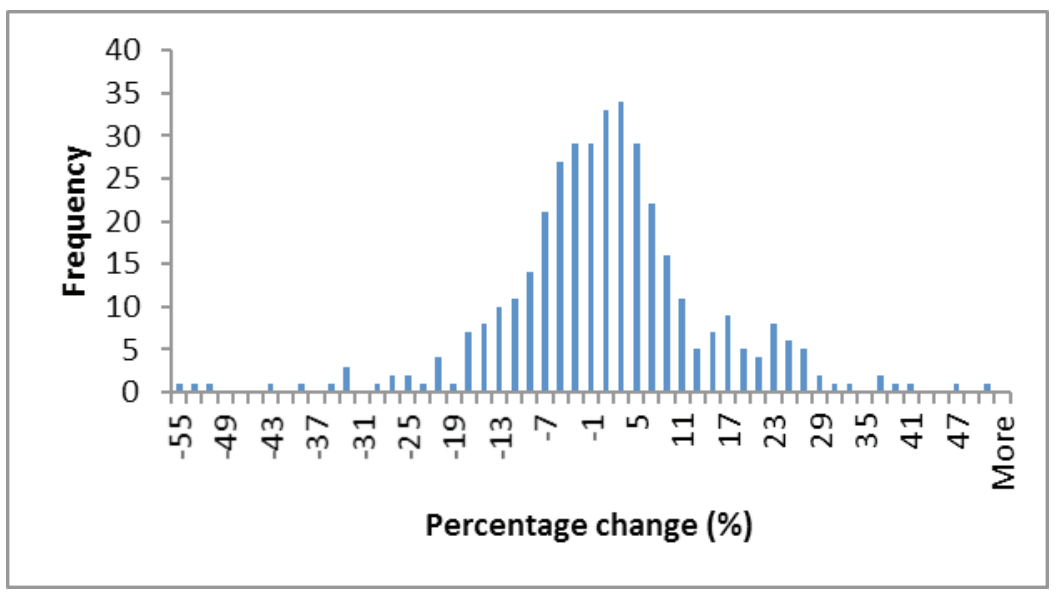

Figure 3: Histogram of Weekly Price Changes 
The yearly descriptive analysis basically gives us a first pass test of time varying volatility of the spot electricity prices. The evidence suggests that in modelling Turkish electricity spot prices, time varying volatility can be an important feature of the price dynamics. Additionally, in modelling volatility, paying attention to the occasional extreme price changes via heavy tailed distributions can improve model fit. Next we will estimate deterministic variance forms for the volatility using well-established functional forms in the literature that takes into account the aforementioned properties of the spot price changes.; i.e. persistence and heavy tails.

Table 4 presents the estimation results. GARCH $(2,2)$ with t-distribution model performs as the best model. The GARCH $(1,1)$ model with GED distribution produces the second highest likelihood and GARCH-GJR with t-distribution model performs the third best. The loglikelihood values for these GARCH_2t, GARCH_GED and the GARCH_GJRt models in Table 4 are $-1474.6,-1474.8$ and -1475.7 respectively.

However, the likelihood values of GARCH $(2,2)$ with t-distribution, GARCH $(1,1)$ with GED, and $\operatorname{GARCH}(1,1)$ with t-distribution are $-1474.6,-1474.8$ and -1475.7 respectively. Therefore, even though, out of the models in Table 4, GARCH $(2,2)$ performs the best in likelihood value, higher order GARCH terms are not the main driving force for the improvement, but $\mathrm{t}$-distribution and GED seem to contribute more to the likelihood improvement. We can also see this by comparing the likelihood value of GARCH $(1,1)$ model in the first row and the GARCH $(2,2)$ specification in the second row. Likelihood improves from - 1489.7 to - 1486.9, however when we estimate GARCH $(1,1)$ with $t$-distribution, the likelihood improves to a much higher value of -1475.7 . This of course should not undermine the effect of higher order terms in modelling persistence (in which GARCH $(2,2)$ performs better), but the point should be taken as the importance of taking into account multiple features of volatility in modelling.

The volatility in the mean equation seems not to be an important dynamic in the electricity market spot prices in Turkey. One interpretation of this can be that market participants submit their bid prices by considering their respective supply/demand conditions and subsequent equilibrium dynamics, but not the overall market uncertainty surrounding the global demand/ supply. Of course, this behavior can be rationalized by the market maker's effort to take the precautionary actions in the case of the mismatches, that is not reflected fully as a cost on the supplier side for instance. The GARCH_2 model captures the price dynamics the better even though the conditional variance is a deterministic function of the parameters and data, compared to the GARCH_1 model as mentioned before. This among other things indicates the importance of modelling persistence in the error process in the weekly electricity price changes. 
Table 4: Model Results 51 (Weekly Data) 52

\begin{tabular}{lll}
\hline Models & Defination & Log Likelihood \\
\hline GARCH & AR(2)-GARCH(1,1)- normal dist & -1489.7 \\
GARCH_2 & AR(2)-GARCH(2,2)- normal dist & -1486.9 \\
TARCH & AR(2)- Threshold ARCH Model & -1492.2 \\
GARCH_GJR & AR(2)-GARCH with a leverage effect & -1489.7 \\
GARCH_M & AR(2)-GARCH(1,1)_M (Std Dev) & -1488.7 \\
GARCH_M2 & AR(2)-GARCH(1,1)_M(Variance) & -1488.5 \\
GARCH_t & AR(2)-GARCH(1,1)- t dist & -1475.7 \\
GARCH_GED & AR(2)-GARCH(1,1)-GED & -1474.8 \\
GARCH_2t & AR(2)-GARCH(2,2)-t dist & -1474.6 \\
GARCH_GJRt & AR(2)-GARCH with a leverage effect-t dist & -1475.5 \\
\hline Weekly Data, Sample period 2010-2017,381 weeks & \\
\hline
\end{tabular}

Also the performance of the GARCH_GJR model with a likelihood value no different than GARCH_1 model signals the weak leverage effect in modeling electricity prices. Accounting for asymmetric responses to negative and positive price changes can help improve model performance in many different markets, however estimation results suggests that electricity market is not one of those markets. Figure 4 draws the estimated volatility series (conditional standard deviation) over the weeks in the sample period. We observe heteroscedasticity in the price process where the conditional standard deviation exhibits significant persistence. All these evidence suggest the importance of modeling volatility in Turkish electricity market. Further research should study various aspects of the volatility, and the dynamics of the price process in the electricity market in Turkey to better understand the main characteristics of this important market.

51 Before defining variance equation, we firstly set mean equation by employing Box-Jenkins Methodology. We found AR(2) model as mean equation for all alternative GARCH type models. In AR(2) model, we checked ARCH effects by employing ARCH-LM test and found ARCH effects. After we estimate alternatife GARCH type models, we again checked ARCH effects and found that there are no significant ARCH effects left in our alternative GARCH type models. We did not present the results in order to save space. The results could be taken from authors upon interest.

52 All alternative GARCH type models' coefficients satisfy the theoretical restrictions on the parameters. We did not present the results in order to save space. The results could be taken from authors upon interest. 


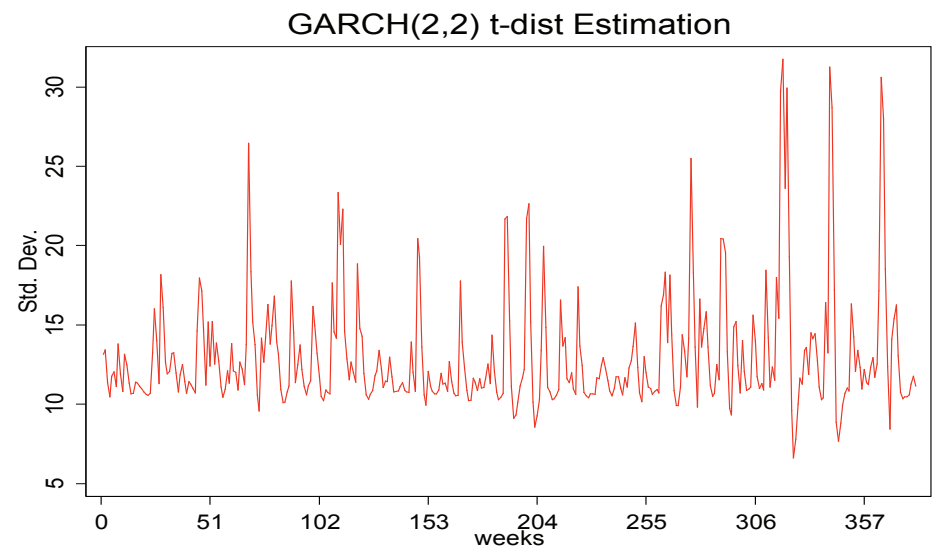

Figure 4: Best Performing Volatility Model for: 2010-2017

\section{Conclusion and Future Research}

In this paper, we estimate the spot electricity price volatility in Turkish Electricity Market using GARCH-type deterministic volatility models. The empirical results indicate that electricity spot price volatility can be characterized by significant persistence and fat-tails in the underlying price distribution. Therefore, we conclude that time varying volatility is an important feature of the price dynamics in Turkey. Asymmetric effects in volatility which is a major characteristic of many commodity markets seems not to be a concern for the electricity prices. In EXIST, price changes exhibit significant variation over years. For instance, 2014 is a year with extremely low volatility where almost no sudden extreme change in weekly prices is observed. On the other hand, 2015 and 2016, and to a lesser degree 2013 demonstrate some large weekly price variations. Therefore, we document that in modelling volatility in EXIST, it should be paid attention to accumulation of large price changes via thick-tailed distributions such as t-distribution and GED, and autoregressive modeling of the conditional volatility. We found that aforementioned nonnormal distributions improve model fit substantially.

These findings have important implications for both the electricity market and for the financial markets at large. It is expected that electricity price volatility can influence other product price volatilities. For this reason, daily forecast of electricity price volatility using best performing wellknown volatility models which take possible asymmetric effects, possible mean effects of the volatility, fat-tails of the distribution and persistence of the volatility series into account, can improve market participants' strategies; for instance, in terms of hedging strategy, volatility spillover or correlations among energy markets. For this reason, a new research direction might be to investigate the possible interactions and spillovers of electricity market with major commodity markets in Turkey. This research is currently a topic we investigate in a separate paper. This 
research, among other things will reveal the possible hedging opportunities via these markets and also will inform us better in terms of the level and change of the electricity spot price volatility in comparison to other markets. Also next research avenue can be the forecasting performance of volatility models including the stochastic volatility. To sum up, at least in this paper, we have obtained some new findings on volatility in Turkish electricity market and this possibly will lead to more studies on the topic quantitatively.

\section{References}

BOLLERSLEV, T., “Generalized Autoregressive Conditional Heteroscedasticity." Journal of Econometrics, 31, 1986, pp: 307-327.

BOWDEN, N., and Payne, J. E., "Short Term Forecasting of Electricity Prices for MISO Hubs: Evidence from ARIMA-EGARCH Models.” Energy Economics, 30(6), 2008, pp: 3186-3197.

BROOKS, C., "Introductory Econometrics for Finance., Cambridge University Press, 2002.

CHAN, K.F., and Gray, P., "Using Extreme Value Theory to Measure Value at Risk for Daily Electricity Spot Prices." International Journal of Forecasting, 22(2), 2006, pp: 283-300.

ENGLE, R. F., "Autoregressive Conditional Heteroscedasticity with Estimates of the Variance of United Kingdom Inflation." Econometrica, 50(4), 1982, pp: 987-1008.

ENGLE, R. F., Lilien, D., and Robins, R., "Estimating Time Varying Risk Premia in the Term Structure: The ARCH-M Model." Econometrica, 55, 1987, pp: 391-407.

ERTUĞRUL, H.M., “Türkiye'de Döviz Kuru Volatilitesi Modellemesi." Unpublished Manuscript, Undersecretariat of Treasury, Republic of Turkey, Ankara, 2010.

ERTUĞRUL, H.M., “Türkiye’de Döviz Kuru Volatilitesi ve Enflasyon İliş̧kisi.” PhD. Dissertation, Hacettepe University, Ankara, 2012.

ERTUĞRUL, H.M., Soytas, M.A., and Ulussever, T., "Short-term Price Prediction in Electricity Market Using Nonlinear Excess Demand Specification., Working Paper, Ozyegin University, 2017.

ESCRIBANO PEAEA, J., and Villaplana, P., “Modelling Electricity Prices: International Evidence.” Working paper, Universidad Carlos III de Madrid, 2002.

GIANFREDA, A., and Grossi, L., "Forecasting Italian Electricity Zonal Prices with Exogenous Variables." Energy Economics, 34(6), 2012, pp: 2228-2239.

GIRISH, G.P., "Modeling and Forecasting Day-ahead Hourly Electricity Prices: A Review." Proceedings of the International Conference on Business Management \& Information Systems, 2012.

GLOSTEN, L.R., Jagannathan, R., and Runkle, D. E., "On the Relation between the Expected Value and the Volatility of the Nominal Excess Return on Stocks.” Journal of Finance, 48, 1993, pp: 1779-1801.

HADSELL, L., Marathe, A., and Shawky, H.A., "Estimating the Volatility of Wholesale Electricity Spot Prices in the US." Energy Journal, 25(4), 2004, pp: 23-40.

HICKEY, E., Loomisand, D.G., and Mohammadi, H., "Forecasting Hourly Electricity Prices Using ARMAXGARCH Models: An Application to MISO Hubs.” Energy Economics, 34(1), 2012, pp: 307-315

HIGGS, H., "Modelling Price and Volatility Inter-relationships in the Australian Wholesale Spot Electricity Markets." Energy Economics, 31, 2009, pp: 748-756.

KNITTEL, C.R., and Roberts, M.R., "An Empirical Examination of Deregulated Electricity Prices." University of California Energy Institute Working Paper PWP-087, 2001. 
KOENIG, P., "Modelling correlation in carbon and energy markets." Cambridge Working Paper in Economics 1123, 2011.

LE PEN, Y., and Sevi, B., "Volatility Transmissions and Volatility Impulse Response Functions in European Energy Forward Markets." Energy Economics, 32, 2010, pp: 758-770.

LIU, H.-H., and Chen, Y.-C., "A Study on the Volatility Spillovers, Long Memory Efects and Interactions between Carbon and Energy Markets: The Impacts of Extreme Weather." Economic Modelling, 35, 2013, pp: 840-855.

LIN, S.X., and Tamvakis, M.V., "Spillover Effects in Energy Futures Markets." Energy Economics, 23, 2001, pp: 43-56.

LINDSTROM, E., and Regland, F., "Modeling Extreme Dependence between European Electricity Markets." Energy Economics, 34(4), 2012, pp: 899-904.

LUCIA, J., and Schwartz, E.S., "Electricity Prices and Power Derivatives: Evidence from the Nordic Power Exchange." Review of Derivatives Research, 5(1), 2002, pp: 5-50.

MUGELE, C., Rachev S., and Trueck, S., "Stable Modeling of Different European Power Markets." Investment Management and Financial Innovations, 2 (3), 2005, pp: 65-85.

MURTHY, G.G.P., Sedidi, V., and Panda, A.K., "Forecasting Electricity Prices in Deregulated Wholesale Spot Electricity Market: A Review." International Journal of Energy Economics and Policy, 4(1), 2014, pp: 32-42.

SADORSKY, P., "Modeling and Forecasting Petroleum Futures Volatility." Energy Economics, 28(4), 2006, pp: 467-488.

THOMAS, S., and Mitchell, H., "GARCH Modeling of High-Frequency Volatility in Australia’s National Electricity Market.” Working Paper, RMIT University, Melbourne (Australia), 2007.

WANG, Y., and Wu, C., "Forecasting Energy Market Volatility Using GARCH Models: Can Multivariate Models Beat Univariate Models?” Energy Economics, 34(6), 2012, pp: 2167-2181.

WANG, K.L., Fawson, C., Barrett, C.B., and McDonald, J.B., "A Flexible Parametric GARCH Model with an Application to Exchange Rates." Journal of Applied Econometrics, 16(4), 2001, pp: 521-536.

WERON, R., "Modeling and Forecasting Electricity Loads and Prices: A Statistical Approach." John Wiley \& Sons, 2006.

WORTHINGTON, A.C., Kay-Spratley, A., and Higgs, H., "Transmission of Prices and Price Volatility in Australian Electricity Spot Markets: A Multivariate GARCH Analysis." Energy Economics, 27(2), 2005, pp: 337-350. 